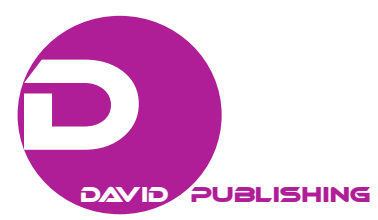

\title{
Laser Weapons: Blinding Laser Weaponry and Its Discontents
}

\author{
Erkan Akdogan \\ Ankara University, Ankara, Turkey
}

\begin{abstract}
In our highly globalized but culturally divided world whereby so-called defense industry is implied as both innovative and progressive, as contemporaneously the international legal doctrine is conceived to be static and conservative. This doubly bound narrative itself is almost as old as international law wherein the most striking contradictory moments happened in the era of, and between two world wars: In such a way that our thinking of legal and other fields owe much more thereto than we realize today. In this study, it is purported to call attention to some key understandings which may be termed as militarist humanitarianism, humanitarian militarism, or, optimist scientism, and pessimist humanitarianism. As such, it is intended to examine international issues pertaining to humanitarianism and militarism through the lens of different perspectives, doctrine-itself and their history as enshrined in the Protocol IV on Blinding Laser Weapons, issues which are almost totally neglected in the mainstream media and academia.
\end{abstract}

Keywords: legal theory, international law, disarmament, arms control, Protocol IV on Blinding Laser Weapons

\section{Introduction}

In one of its most controversial cases, the International Court of Justice stated in passum as follows:

(sic) Since in international law there are no rules, other than such rules as may be accepted by the State concerned, by treaty or otherwise, whereby the level of armaments of a sovereign State can be limited, and this principle is valid for all States without exception ${ }^{1}$.

Therefore, in principle and according to the World Court, there are two sets of "rules" to be distinguished from each other. First, there are rules, the negation of which permits states to adopt their own policy to determine the level of their armaments. These rules are defined by their absence: absence of "treaty or otherwise”. As such, the Court's selection of wording is striking. By inclusion of "otherwise", the Court implies that there may be absence of rules of international law other than treaties. In our opinion, these refer to formal sources of international law other than treaties, e.g. customary rules and so on (Statute of the ICJ, Art. 38). Second, there are also rules, the existence of which depends on acceptance by a state, and delimits the level of armaments of that state. In this set, too, rules may be composed of "treaty or otherwise". However, in this case, the acceptance of a state seems to be explicitly mentioned. In other words, in the Court's construction, although these two sets refer to two different legal consequences, they both embody a principle which is legally

Erkan Akdogan, Ph.D. candidate, School of Social Sciences, Ankara University; research assistant, Department of International Law, Law Faculty, Ankara University, Ankara, Turkey.

Correspondence concerning this article should be addressed to Erkan Akdogan, Ankara University Law Faculty, Cemal Gursel Cad. No. 58, Cebeci 06590, Cankaya, Ankara, Turkey.

1 Military and Paramilitary Activities in and against Nicaragua (Nicar. v. U.S.A.), Judgment, 1986 I.C.J. Rep. 14, ๆ 269 (June 27). For citations, the Bluebook is followed herein, unless otherwise mentioned, cf. The Bluebook: a Uniform System of Citations, Twentieth edition, Cambridge, The Harvard Law Review Association, 2015. 
valid for each and every sovereign state. In sum, there are rules which delimit the level of armaments; and there are also rules that do not by their absence; both sets and both absence and presence are conditioned by the acceptance of the state concerned to which such rules shall apply.

Provided that there is the decision, a prejudgment, let us ask: how could the World Court decide otherwise? In our opinion, such indeterminacy or prejudgment is inscribed, consciously or unconsciously to the core of international law. For instance, as per 1977 Additional Protocol I to the 1949 Geneva Conventions,

In the study, development, acquisition or adoption of a new weapon, means or method of warfare, a High Contracting Party is under an obligation to determine whether its employment would, in some or all circumstances, be prohibited by this Protocol or by any other rule of international law applicable to the High Contracting Party. (Protocol I 1977, Art. 36)

In other words, whether the employment of a "new" weapon or means or method of warfare is prohibited legally shall be determined legally by each state-party to the Protocol, in some or all circumstances. Though, we are told that it is intended not to "make the outcome of national assessments internationally binding", then it is quite considerable if the reason why such Article is agreed on: "dubious means or methods of warfare will be introduced only after a finding of legality" (Anderberg, Bring, \& Wolbarsht, 1992). Please also note that the two "legally" we mentioned differ: the first qualifies the prohibition itself while the second, arising out of the Protocol I, qualifies the determination as such, as an obligation. All in all, this constitutes a repetition of one of the core international humanitarian rules (Pictet, 1966; Berman, 2004-2005; Kennedy, 2006; Lewis, 2008-2009; Corten, 2005; Koskenniemi, 1997), in a nuanced way. Namely, as enshrined in Saint Petersburg Declaration (1868), the engagement taken by states-parties is to "engage mutually to renounce, in case of war among themselves, the employment by their military or naval troops of any projectile of a weight below 400 grammes, which is either explosive or charged with fulminating or inflammable substances" (St. Petersburg Declaration, para. 1). Whereas states agree that such engagement is legally compulsory only upon the states-parties and not legally applicable to non-state-parties. Therefore, there are at least two principles, each double bound: one related to armaments of a state in a double sense as mentioned further above, other related to their use in double sense (use of force, and when used use of weaponry). In sum, "law is law" (Lyotard \& Nancy, 1985, not. pp. 115, 119, 121-122; Zizek, 2008, pp. 95, n. 35, 203-209, 226-227, n. 30; Chazel \& Commaille, 1991, pp. 95-99, not. 96; Deleuze, 1993, not. pp. 7-41) ${ }^{2}$.

The idea here is not to undermine or to blame efforts on international humanitarian law, human rights law, law of armed conflict, or international law in general. It is, rather, to delineate the kaleidoscopic nature thereof, especially in respect to their shared history, now almost being forgotten. In our opinion, such nature had been known to and developed by the inter-war international legal discipline purported to limit the state sovereignty, militarism or war through the advent of the Treaty of Versailles, League of Nations (predecessor of the UN), Permanent Court of International Justice (predecessor of the World Court), Briand-Kellogg Pact, proposals for (following French proposal) a Union of Europe, and so on. The context of interwar period whereby pacifism is thought to be bound to security, security to disarmament, disarmament to economics, economics to international organization, organization to judiciary, judiciary to treaties, treaties to conferences, conferences to pacifism is embedded to such construction, and scholarly examples, especially debates based on these

\footnotetext{
${ }^{2}$ For the assessment, insight and critique, cf. Derrida, Préjuges: Devant la loi dans Lyotard et al. This "double-bind” may be, in a specific sense, termed as "collective hypocrisy" as well, cf. Bourdieu, Les juristes, gardiens de l'hypocrisie collective dans Chazel, Commaille. For an introduction to the repetitions and differences, cf. Deleuze. References herein to works in different languages are made with respect to their difference.
} 
assumptions are many and illustrating (Wehberg, 1919; Politis, 1925; Lauterpacht, 1934). In the 1920's and around until 1935, one way or another, the so-called arms industry was legally, illegally or legally for some still illegally for others, developing, multiplying, and expanding worldwide (Krause, 1995, pp. 72-79; Braithwaite \& Drahos, 2000, pp. 15-26): Japan entered Manchuria, Italy to Abyssinia, Bolivia and Paraguay were at war, or rumors sounded much more strongly against German rearmament contrary to the Treaty of Versailles but suspected under the Rapallo Treaty till Germany publicly renounced the disarmament clauses of the Versailles, etc. International legal doctrine responded to these developments and troubles, "crises" in a double movement. Namely, while politics of armaments were legalized, rules on armaments politicized (Bliss, 1926; Noel-Baker, 1927; Scelle, 1934; le Fur, 1934; Ray, 1936) ${ }^{3}$. As proven by numerous instances, e.g. the then naval or air armaments, the ambiguity of terminology hint the crucial part of the story itself. How to name the phenomenon and what to understand thereof, what meaning such name would refer to, or do we really mean what we name, and so on. In inter-war context, shall we say disarmament or limitation of armaments (Wehberg, 1925; Niemeyer, 1928; Efremoff, 1932; Kunz, 1929; von Oertzen, 1931; Tönnies, 1929)?

We believe that this indeterminate or rather vague scheme, though transformed and comprised of the trilogy of disarmament, international organization and adjudication, is still actual. Taking the case of nuclear weaponry which has always been a popular theme since 1945, on which the World Court stated, much to the dismay of the anti-nuclear activist and contradictorily, to the pro-nuclear: (sic) although the threat or use of nuclear weapons would generally be contrary to international law applicable in armed conflict, in particular to the humanitarian law,

(sic) In view of the present state of international law viewed as a whole, as examined...by the Court, and of the elements of fact at its disposal, the Court is led to observe that it cannot reach a definitive conclusion as to the legality or illegality of the use of nuclear weapons by a State in an extreme circumstance of self-defence, in which its very survival would be at stake. (Advisory Opinion, 1996, para. 97)

Neither the activist is satisfied nor the pro-nuclear. A similar case in the sense of law, human rights, and humanitarianism is also valid for conventional weapons and laser weaponry. Weapons as such are also prime examples of indeterminacy, deletion of which would not only prohibit the discourses built thereupon but also engender new discourses, struggles to pursue, fronts to battle, arguments to make. In short, international discourses on weapons, in this vue, are also on "identity", and each a "sport de combat".

\footnotetext{
${ }^{3}$ For a treatment of the subject, though somewhat pessimistically but classical of its time, cf. Noel-Baker. Compare also the idea of the 1920's with the replies from France to the failure of the disarmament effort in the 1930's, esp. due to withdrawal of Germany (1933) from the League of Nations and the Disarmament Conference, cf. Scelle and le Fur. But see also Ray.

${ }^{4}$ The irony is, concurrently, that German rearmament against the provisions of Versailles had already been at work as proved by Ponton-Prozess, Weltbühne-Fall etc. We will follow this line of symbolic historic events in an upcoming article, as well.

${ }^{5}$ This opinion has been extensively discussed, harshly criticized and there exists a vast literature on the subject. We would like to ask: how could the Court have opined otherwise? The general and comprehensive ban on nuclear weapons, as proven and reached by the 2017 Treaty on the Prohibition of Nuclear Weapons and repeated regularly in several UN General Assembly decisions, needs to be also addressed comprehensively. For instance, such a ban would also result in the prohibition of the nuclear industry's core components or military and personnel attached to such use, including nuclear physicians or controllers. Moreover and much more importantly, the Court unsurprisingly refused to deny use of nuclear weapons, which, almost half a century ago paved the way to end the Second World War. Without directly addressing and unable to address such issues with the then vocabulary of law, e.g. the violence which enabled law as such, it would be naive to think that nuclear weapons would be banned once and for all. Please note that our main concern is also the general and comprehensive ban of nuclear weaponry, but the problem remains, "how to bind sovereigns without or contrary to their own consent?" Please also note that this is another instance of the law's “double-bind". For the 2017 Treaty, cf. UN Doc. A/CONF.229/2017/8, 07.07.2017, available at: http://undocs.org/A/CONF.229/2017/8 [15.11.2017].
} 


\section{Conventionality of Laser Weapons: Between Humanitarian Militarism and Militarist Humanitarianism}

Conventional weaponry may be defined by what it is not, and ironically, vice-versa. As well, legal regime applicable to, and the understanding thereof differ as per the weaponry though the basic premise of the thinking, “double-bind” remains, "conventional” is conceived vis-à-vis "unconventional” whereby "unconventional” is conceived vis-à-vis “conventional” (CCW, 1992).

To us, the problem is, mainly, what makes a weapon, any means or method of warfare "conventional" and what makes it different from "unconventional"? In this double sense, these are neither easy questions to ask nor there could be given shortcut replies. Let us consider the plurality of discourses on the subject with special references to the city or cities where many of the rules were enacted. To human rights (New York-Geneva) it is prohibited to kill; to law on use of force (Paris) war is prohibited whereby self-defense is allowed; to law in war (the Hague) it is shown how to kill in war; to international humanitarianism (Geneva) it is permitted to kill some via prohibition to kill others in war; still, in arms control (Vienna) some armaments designed to kill are controlled, verified, or banned; in law of armed conflict (Hague-Geneva-Vienna) some are banned, others are allowed; in law of weaponry (Hague-Geneva-Vienna), weaponry itself is legalized, allowing some, permitting others (Boothby, 2016, p. 3; Kalshoven, 1985) ${ }^{6}$.

As a side effect, adopting such a point of view requires a certain vocabulary, a modus operandi and implying consequences unseen as well. And along with them, on how to deal with questions in a specific discourse, generally unable to communicate with the other, and each dictating its own terms and conditions to the reader. For example, let us take the purpose of the law of the armed conflict. Law on the use of force (UN Charter, Art. 2, 51 ${ }^{7}$ ) restricts the use of force to self-defense; however "armed conflicts" do not end. As noted above in the Nuclear Weapons Opinion, the logic is already very familiar: "it is prohibited... but..." This is the rationale behind "law of the armed conflict", by "preventing the degeneration of conflicts into brutality and savagery...aids the restoration of peace and the resumption of friendly relations between the belligerents" (UK Manual, 2005, ๆ 1.8, p. 3). Thus, all in all, law of the armed conflict, law and conflict together, constitute a way to restore peace and resume friendly relations. Since at least Saint Petersburg Declaration,

The main purpose of the law of armed conflict is to protect combatants and non-combatants from unnecessary suffering and to safeguard the fundamental human rights of persons who are not, or are no longer, taking part in the conflict...and of civilians. (UK Manual, 2005, p. 3) ${ }^{8}$

\footnotetext{
${ }^{6}$ On plurality of points of view that might be adopted and for the institution of "law of weaponry”, cf. e.g. Boothby. (Yoram) Dinstein presents Boothby's "oeuvre" as follows: (sic) "This volume is likely to become the leading oeuvre on the legality of recourse to weapons in wartime”, ibid., p. ix. Without dealing with this "legality” itself, which differs from other "legalities” of other legal regimes (human rights, humanitarian law and so on) it seems improbable for us to address questions of "legality” or "legitimacy” of a general and comprehensive ban of any weaponry. For a theatrical approach on "international affairs" regarding these issues, cf. Kalshoven.

${ }^{7}$ For the World Court, taking into consideration the US reservation to the Court's jurisdiction, providing that when the US does not specially agree thereto and by excluding application of multilateral treaties in case not all states parties to such treaty are parties to the dispute, prohibition to threat or use force is also part and parcel of international law, cf. e.g. Nicar. v. USA, ๆ 45, 56, 172. The Court seems to opt for relying solely on treaty law whenever possible while announcing that for a state against whom force is used, other than self-defense (esp. UN Charter, Art. 51), there are “(o)ther means... available..., including, in particular, recourse to the Security Council” of the UN, cf. e.g. Case Concerning Armed Activities on the Territory of the Congo (Dem. Rep. Congo v. Uganda), Judgment, 2005 I.C.J. Rep. 168, ๆ 148-149, 164-165 (December 2005). The Court declares not any use of force would constitute a breach of the law, however. In order for a breach to occur, use of force would have "such a magnitude and duration" as well, ibid., p. 165.

${ }^{8}$ On this, from a perspective of an expert, see Coupland (1996).
} 
In other words, in an "armed conflict", “combatants" would "neutralize” enemy provided that such "combatants" shall not cause unnecessary suffering. Or, they are not obliged to safeguard the fundamental human rights of "persons" who are part of such conflict. In common language, soldiers become persons, persons become soldiers as per the context, namely, the armed conflict itself.

As another instance, the authoritative commentator on Protocol I 1977 opines that "quite independently of the problems of" weapons of mass destruction, "all predictions agree that if man does not master technology, but allows it to master him, he will be destroyed by technology" (Sandoz, Swinarski, \& Zimmermann, 1987, pp. 427-428) ${ }^{9}$. Therefore, in this sense, as for the World Court opining on nuclear weapons, there are some matters relating to "survival", survival of man or survival of a state, and so on. Please also note that the "quite independence" of some weapons, namely "weapons of mass destruction" is depicted as another case at hand in the above quotation. In such a sense, one remains suspect of such weapons' relation to technology between the images of nuclear catastrophe and, as in arms control discourse, "verification” (Goldblat, 2003. p. 309). Seen from the side of the technology, however, when taken to defense industry, the picture changes as well. Main loci transform (Crawford \& Koskenniemi, 2012, pp. 158-183; Koskenniemi, 2010) to actors rather than states, to standards rather than norms, to process rather than adjudication, to contract bargaining rather than diplomacy, to governance rather than administration; activists become company men if not conciliators, combatants become personnel; companies become contractors where military command or governors turn into owners or employers; budgets or defense planning turn into requests for proposals or defense projects; jurists replace soldiers, managers replace judges; proxies, shareholders, or advocates of peace replace court personnel, audition, or lawyers... Unable to bring armaments, arms, weaponry, or the discourse or vocabulary which enables as such to exist to an end, much more energy, we are told, shall be poured into transforming the discourse or vocabulary itself, wars become armed conflicts, disarmament arms control... It is in this sense that privatization of war goes hand in hand with economization, rearrangement of work share, international private organization and humanitarian action. Not only international law expands to govern newly discovered fields, to produce subfields, and to enhance specialization, it also becomes privatized, fragmented, economized, naturalized, marginalized etc. And, in our opinion, this kaleidoscopic nature is due much to the contribution of before and especially interwar international discourse, including but not limited to the international legal doctrine-itself ${ }^{10}$.

Conventional weaponry, by being tied to technology and military command as such, is conceived to be tactical, aimed only at military targets, giving tactical advantage over the enemy, destined to neutralize the hostile military forces. While, on the other hand, weapons of mass destruction are, either strategic or tactical, "have characteristics comparable in destructive effect to those of the atomic bomb" including nuclear, chemical, or biological weapons and also any "weapons developed in the future” (Goldblat, 2003, p. 42; Tuzmukhamedov, 2015; Nuclear Weapons Opinion, 1996, I 56-63). By these very characteristics, such weapons, being "unconventional”, differ from "conventional" ones, thereby conditioning conventional weapons as being any weapon "not having mass destruction effects” (Goldblat, 2003, p. 34; Tuzmukhamedov, 2015, pp. 397-398). And as such, whether blinding or not, any laser weapon would be deemed "conventional” whereby for chemical weapons, for instance, "riot-control agents" used in internal disturbances are out of the scope of international

\footnotetext{
9 Jean de Preux, Article 36-New weapons in Sandoz, Swinarski, and Zimmermann (1987).

${ }^{10} \mathrm{We}$ (maybe we need to define who we are) are of the opinion that the prime example is the League of Nations, an international organization supplementing the peace treaties, while transforming state-centered colonialism to internationally supervised mandate system, purported to secure disarmament, to provide enactment of inter-state legislation, and to support adjudication by arbitration.
} 
legal discourse (Henckaerts \& Doswald-Beck, 2009, p. 259) ${ }^{11}$. In other words, the twin logic of permission-by-prohibition and "it is prohibited... but...” while sustaining or deferring inter alia national in, or, to international are internalized, naturalized, legitimized, legalized etc., inscribed to the core of the doctrine-itself. In sum, the main problem is "conventionality" of any "weapon”.

From human rights activists to campaigners on humanitarian actions, we think that in waging a moral or humanitarian war against war, one should bear in mind the logic and its basic modus operandi delineated above, which may be concretized as follows. As depicted very well in a documentary on the "First World War", once a field marshal—reading below, one can easily doubt who he could be or his nationality—scandalously put it as a lesson, indeed at least two lessons - in a letter to an international lawyer in 1880, and thus - the soldiers on the front in 1914 are instructed by the German Headquarters accordingly: “...international rules do not work when soldiers are in constant fear for their lives while a civilian (franc-tireur?) may pick up a rifle and shoot them”. The second one-though in the letter, there are several parts worth mentioning as well-are even more scandalous: "...it must also be remembered that the greatest...deed in war is the speedy ending of the war, and every means to that end...must remain open”. In other words, when an "armed conflict” begins, "rulership" deems that, at best, the easiest and shortest way to end "superfluous injury" or "unnecessary suffering" of the enemy is to win the war, defeat the enemy, annihilate the opponent as soon as possible, and "every means to that end" shall be permitted while, it may be interpreted not to exclude principle of proportionality in warfare. Thus, in this narrative, humanitarianism blends with the so-called preussische Militarismus, but then, it is neither innocent, naive humanitarianism nor naked, brutal militarism. It is, rather, militarism offered in humanitarian clothes, humanitarian militarism. And, in both of the receiving ends, this dictum shall be obeyed, e.g. as Kant once put it, "you can, because you must”. Therefore, e.g. as the same documentary goes on to avoid Franco-Belgian civilian snipers for military snipers in the front lines reminded soldiers to enjoy their out-of-battle time in quiet fronts (Wehberg, 1920; Kalshoven, 1985, pp. 191-204) ${ }^{12}$ that they were actually in war, civilians may be used as a shield to marching troops or houses where snipers would likely to be deployed,

\footnotetext{
${ }^{11}$ The logic here is differentiated from that of the nuclear weapons, although premises remain at a basic level ("it is prohibited... but...”), International Committee of the Red Cross' ambitious compilation of customary law includes the basic rule on chemical weapons. As per Rule 74, “...use of chemical weapons is prohibited”, and under Rule 75: “...use of riot-control agents as a method of warfare is prohibited”. Therefore, via these 2 (two) prohibitions, it is implied to permit that "domestically”, states are allowed to use e.g. tear gas. In other words, what is banned against enemy forces, is allowed against civilians home, though in a much lower degree, in a nuanced fashion. The idea, we are told, is that using such agents would provoke the enemy to counter by the banned chemical weapons in war, however since the civilians on home soil are unable to do so, then let us use such agents against them whenever necessary and in peace since it is not prohibited legally.

${ }^{12}$ Bulk of the mainstream media and academia enjoys focusing on big military events and esp. in history, like Sedan, Verdun, Gelibolu etc. in the Great War. However, in "quiet fronts" where military action was minimized, "hostile" soldiers adapted to war, and war is adapted to them: consider mottos like "live and let live" or "do not fire at us and we will not fire at you". According to the same documentary mentioned above, around 1916, German soldiers warn their British counterparts before an artillery raid by a letter where they prescribe that before the artillery fire they would blow a whistle so the British would take cover. Or, take the example of British and German officers on "meal courtesy", not to interrupt each other's meal time. And also, we should mention that these instances occurred while in others, there were heavy mortars, gas warfare, killings of prisoners of war or civilians etc. When Germans launched full offensive in 1918, by manpower, material and strategy all were lost for them in around six months. Typical of "commanders" and "rulers", what all German command would do were to blame home front, find scapegoats and criticize any "other...inside", with skillfully avoiding any public self-critique. As the mainstream history put it, this is why and how millions died on the front lines caused by poor planning, execution and management though the command refused the loss, the legend of Dolchstoss (stab-in-the-back) born and plagued the upcoming years on losing side. When returned home after the Armistice in 1918, e.g. the footage showing German Army welcomed by thousands in Berlin as if they were the victors of the War, and the parade there is striking. We will follow these, among others, in a separate article on pacifism in the context of inter-war international imagination and culture of Weimar era.
} 
should be put on fire sometimes amounting to burning villages! Conversely, in such a scheme it is not permitted, especially for a soldier or a military lawyer, to question the order of the ruler, since, e.g. as Kant also put it, "you cannot, because you must not”. This version of humanitarianism is much more familiar to us. As seen in today's humanitarianism offered as humanitarianism cloaked in militarism, by shifting focus solely to the receiving end of the violence as a humanitarian, humanitarianism turns to militarism, it becomes militarist humanitarianism. We suspect that, in this case, not only the logic and modus operandi of the ruler are naturalized, legitimized, legalized etc., but also a crucial point is missed, written out of the discourse not to be seen totally, that the one, the human being receiving the violence can easily happen to be a civilian. In contrast, in the midst of a violence one may notice that the "combatants" are not those who conduct the war, there are civilians, especially politicians were the ones who conducted the war. For instance, in the same documentary, a German soldier recounts that one day, when they were cooking meal in the trenches, a French shell fell, asking "could the French join?” Upon invitation and thereon, the French were agreed to meal whenever Germans cooked.

We believe that laser weaponry suits to above scheme very well. Now, we will try to see how it works between optimist scientism and pessimist humanitarianism, as concretized in Protocol IV.

\section{Object and Purpose of the Protocol IV on Blinding Laser Weapons: Between Optimist Scientism and Pessimist Humanitarianism}

Laser technology may be employed in the battlefield both as an accessory, a device, a component to another weapon (e.g. range-finder, target designator, military training) and as a weapon, lethal or non-lethal, itself against air, naval or land targets. Some experts demonstrate that the experiments on use of laser energy for military purposes date back to late 1950's (Anderberg, Bring, \& Wolbarsht, 1992, p. 290; Downs, 2007; Fidler, 2001). Whether designed as an anti-personnel or anti-matériel, using low energy level or high energy level, as an expert put it, recently,

...fascination and appreciation of modern weaponry is at an all-time high (CNBC: Defense, 2017; Jane’s 360, 2017; Defense News, 2016) ${ }^{13}$...Armed forces in many countries are already using a great number of laser devices, and the inexorable pace of progress in developing special laser weapons indicates that they will ultimately revolutionize the modern battlefield. Practically invisible when fired, silent, capable of pinpoint accuracy, and travelling at the speed of light, laser weapons would seem to offer unparalleled advantages over conventional weapons. (Zohuri, 2016, pp. 1-2; Downs, 2007, pp. 368-369) $)^{14}$

Please note inter alia the wording, "fascination" and "appreciation" along with "practically" and "unparalleled advantages". So, for the expert, as a device, laser technology is widely used, however, there would be much use as a weapon. We term this stance as “optimist scientism”. Nevertheless, as indicated above, for others laser energy as such brings consequences to the health of combatants, though, at best as a side effect

\footnotetext{
${ }^{13}$ News agencies report that a defense company is awarded a contract, that “...is valued at $\$ 26.2$ million, but the potential market opportunity for such airborne weapon systems in the future could become significant once technology challenges are overcome”, so that around 2021 fighter jets would be equipped with such technology. Similar plans exist for other states as well, including projects which would "offer highly accurate targeting, allowing it to hit specific parts of an aircraft...”. In 2016, UK Ministry of Defense awarded a £30 million project.

${ }^{14}$ However, writing in the US, working for a US company, dealing with a US project, the expert or a humanitarian, after a while, turns into a company man or a commander, and employees thereof turn to be soldiers, not out of nowhere but “...for... defense of... country. A better weapon in hands of...arm force to carry on such defensive task. Any employee found to have violated these policies and procedures may be subject to disciplinary action up to and including termination of employment”, ibid., p. 2.
} 
it may cause collateral damage. We term this stance as "pessimist humanitarianism".

We are of the opinion that both of the stances have their limits in their imagination. In this vein, in an often cited Report by experts at International Committee of the Red Cross (ICRC) from the 1970's, the most remarkable statements are included in the Chapter VII entitled "potential weapon developments" 15 . We think it would be quite illuminating to closely follow the argument therein, since, resembling the commentator on Protocol I 1977, it is much more pessimistic with regard to technological progress' implications on humanitarian affairs, but, not "over-pessimistic", in its own wording. But, as in the case of the above mentioned expert or the World Court's statement on armaments, here too, the Report informs us that though there is much energy devoted to military technology by the States, "for a variety of reasons, among them the secrecy which is customarily maintained by States around their military affairs, speculation as to which of these new developments will come, as it were, to fruition, can only be uncertain” (ICRC, 1972, p. 65). Since, in the field of military technology whereby almost anything is kept secret, that is what the "ruler" defines as such (HRW, 1995; Carty, 2002, pp. 44, 55-56; Sands, 2005; UK Iraq Inquiry Committee, 2017, ๆ 3.1, pp. 381-383) ${ }^{16}$. So, the problem transforms into knowing what we know or what we do not, and unknowing what remains unknown to us or what is known. For instance, we know that there is laser technology developed to be used in warfare but we do not know if there is any laser weapon used directly on battlefield (=known unknown). Or, maybe the soldiers on the field use laser technology directly as a combat weapon, but they do not know that they use it actually (Zizek, 2006; Rumsfeld, 2011, pp. 1-2) ${ }^{17}$ (=unknown known). So, at the time Report was drafted, we induce that what is known to be unknown was, "in the laboratories...there must be many potential weapon developments" though even to those scientists, experts in the laboratories may not know what they know, since "whole areas of science, which hitherto had made little contribution to weapons technology, now have a relevance which few would have predicted in earlier decades" (ICRC, 1972, p. 65). However, what made "pace of progress" "inexorable" in the above mentioned expert, the trends depicted by ICRC experts do not demonstrate such to be "inexorable", in a way to resemble the commentator on Protocol I 1977. And, though we know that we do not know everything on potential weapon plans, we are told by the Report that we need not be "over-pessimistic", since "apart from anything else, they are subject to budgetary constraints which are under political control” (Fleischmann, 2015; Downs, 2007, p. 379). Therefore, the Report sends back the answer of the question to the core, where it stems from. Moreover, it indicates that there is a threshold, even for pessimist humanitarianism: for humanitarian purposes, one may be pessimist, but should not be over-pessimist to denounce technology completely. This way, humanitarian militarism and militarist humanitarianism we mentioned earlier, hereby transform somewhat ambiguously to the indeterminacy between optimist scientism and pessimist humanitarianism: their main difference being the first focuses on progress on technology and its

\footnotetext{
${ }^{15}$ ICRC, Weapons that may Cause Unnecessary Suffering or have Indiscriminate Effects: Report on the Work of Experts, Geneva, 1973, p. 70 et seq. and compare Zohuri, p. 1 on "tight security” wherefore the expert bases information on "open literature”.

16 To HRW in 1995, "aggressive state of development of tactical laser weapons within the U.S. military, which heretofore has been mostly shrouded in secrecy, makes a ban on tactical laser weapons and on blinding as a method of warfare more urgent now than ever before", ibid. From the perspective of humanitarian discourse, this necessary recourse to and function of the "secrecy" is the side effect of the logic and one of the demonstrations of the modus operandi we mentioned earlier. Secrecy is also a key issue with regard to arms control discourse, esp. on "verification" and "compliance", please note that secrecy, knowingly or unknowingly would amount to grave errors, even serious doubts on, if not usurpation of legality of the use of force, the prime example being the Operation Iraqi Freedom (2003).

${ }^{17}$ On this, see Zizek. For the ridiculous statement and still reluctant or ignorant of the "unknown knowns", see the account of (Donald) Rumsfeld as well, and compare with the findings of the Iraq Inquiry (Chilcot) Commission's Report
} 
positive results excluding any danger, while, for the second, risks and dangers of technology are internalized while any excess is excluded.

Through the end of the 1990's, a period comparable to inter-war period (1919-1939) in many ways, a commentator on the role of humanitarian issues on international politics opined that, "humanitarian issues played a historically unprecedented role in international politics...The experience of this expanded and largely unforeseen role raises questions for theorists and practitioners alike" for both those who believe in power politics and those believing in relevance of international humanitarianism (Roberts, 1999). Much more than that, and repeatedly, legalism, progressivism, humanitarianism and other ways of thinking turn to "pactomania" of the 1920's but in a different version. If any concern for humanitarian action arises let us call for state action, write a pamphlet on the subject, gather a conference to draw up a convention to intervene: What else could be done? However, the two periods sharply differ if we take the resulting treaties or conventions into consideration, fail or not, and without regard to their "not-imperfectness" (Pomme de Mirimonde, 1920, not. pp. 5-17). After 1989, but especially after 2002, the treaties or conventions differ as to their normativity, and in a very striking way: they have become arrangements or agreements more of an informal or non-binding character (Koskenniemi, 2005, pp. 66-71). The titles tell too little of the story: materially, general and objective international laws have given way to transnational or global standardization, or governance in a multicultural fashion as if given out of nowhere, e.g. ISO-9000. And, as if those tending to perpetuate are solved, more and more new phenomena interest international legislation or international legal discourse. For instance, new rules are adopted, new conventions are enacted, brand mechanisms and strong bureaucracies are created though, the same contain little or no norms nor forms, for the sake of e.g. attracting participation by as many as states as possible while the main thrusts of the same are refused or minimized by those that partake in the phenomena themselves. In the interwar period, there has been lesser number of states dedicated to international-legislation that were much more normative but less effective than today. After 1989, although attracted by many states than ever before, they tend to be less normative but, ironically, seem to be much less effective. It would be enough to recall the (2017) Convention on the Treaty on the Prohibition of Nuclear Weapons whereby nuclear weaponry is outlawed, but no nuclear power adhered thereto, on condition that even if they adhered thereto they would comply with it in full. So, who could blame the Treaty-itself?

One may read the Protocol IV on Blinding Laser Weapons (Protocol IV, 1996; UN Secretary General, 2017) taking above mentioned contingency, complexity, or indeterminacy into consideration. Protocol IV was agreed to by the CCW Review Conference of the States Parties in 1995 whereby blinding laser weapons are banned, though there have not been any precedents thereof to be actually employed. Originally, CCW included three Protocols, not deemed to cover laser weaponry as such. Namely, Protocol I regulates non-detectable fragments, Protocol II regulates mines, booby-traps and other devices, and Protocol III regulates incendiary weapons $^{18}$. Since the CCW is only a framework agreement, for the sake of "flexibility", which relies on particular agreements to be concluded in the forthcoming future, and the three Protocols have not covered any possible development of a conventional weapon, e.g. laser weaponry, that would be excessively injurious or have indiscriminate effects if used, Protocol IV is concluded in the first session of the Review Conference of the CCW to govern the issues related to blinding laser weapons. However, this had not occurred by itself or momentarily. Though proposals in the Conference adopting the CCW were dropped, the concern for laser

\footnotetext{
${ }^{18}$ For the texts of the Protocols (I to III) to the CCW, cf. 1342 UNTS 168 (1992) and 1342 UNTS 171 (1992).
} 
weaponry has grown in time. As such, Protocol IV and the participation thereto are due much to the efforts of the ICRC and Sweden (Parks, 1997, p. 34; Doswald-Beck, 1996; Peters, 1996; Goldblat, 2003, p. 287; Boothby, 2016, p. 202) ${ }^{19}$. We are of the opinion that, the Protocol IV is best understood the logic which caused its emergence, the driving humanitarian force behind it. Before the adoption of the Protocol IV, and after the "successful” Operation Desert Storm (1990-1991), we are told that: "almost every kind of laser device...except laser weaponry, was used in large numbers during the conflict", and since "one of the main objectives during the air campaign besides hitting the enemy forces was to minimize civilian losses and damage to nonmilitary facilities", the war "demonstrated the usefulness of different laser devices on the battlefield in assisting weapon systems, commanders, and soldiers” (Anderberg \& Wolbarst, 1992, pp. 7-8; Parks, 1997, p. 33; ICRC, 1973, pp. $65-67)^{20}$. Nonetheless, along with this enthusiasm, there came the darker sides of the story, e.g. civilian casualties, destruction of infrastructure etc. (Lewis, 2003). Therefore, paradoxically, it is the war and its inhumane consequences themselves which are the nest for humanitarianism or legalism. For instance, in the narrative above, there are at least two main objectives: one is hitting the enemy; other is minimization of civilian losses and damage to nonmilitary facilities. When combined, it is militarism (=hit the enemy, or kill the enemy soldier), but cloaked in humanitarianism (=try not to hit civilians, or =try not to damage enemy soldier's eye).

In our interpretation, it is in this understanding that without any actual use in battlefield, blinding laser weaponry could have been outlawed (UN Secretary General, 1972, ๆ 184; Carnahan \& Robertson, 1996) ${ }^{21}$, with exception of or implying to exclude antipersonnel uses of laser weaponry, in other words, direct use of laser weaponry against human beings, enemy soldiers.

\section{In and Out of Scope: Laws, and LaWS/LAWS/LAWs}

In military vocabulary, there are several meanings attached to the specific letters and their specific combinations, e.g. including the letters l, a, w, s. For example, "LaWS" stands for "laser weapon system" specifically designed for and put to use for the US Navy. However, when used as "LAWS", this means "lethal autonomous weapons system"; in short, robots, robotic warfare. Moreover, if we use "LAW", or its plural form "LAWs", we mean "light anti-tank weaponry" or "weapons”. As a student of jurisprudence, there remain us the "laws" as we know them: law of war, law of peace, law of armaments or law of weaponry, law of armed conflict, law in war, law after war etc. The plurality of that denotes much more than what is implied thereby. In this section, the Articles of Protocol IV will be analyzed more closely while demonstrating examples of

\footnotetext{
19 For the background compare (US military) Parks, Doswald-Beck, and Peters. In arms control, the approach is more legal-technical, cf. Goldblat, p. 287 et seq. In law of weaponry, however, the approach is more humanitarian, still legal, cf. Boothby.

${ }^{20}$ For the qualification of this oeuvre as the "basis for a renewed effort by Sweden to regulate or prohibit the use of anti(-)personnel laser weapons or other lasers for systematic blinding of...combatants”. Compared to these assessments, expert view is more pessimist: in the ICRC Report we cited earlier, the potential development in weaponry is foreseen to include increases in fire power, mobility, armor, but also vulnerability of the individual soldier, dependence upon electronic, electro-optical systems for communications, target acquisition and guidance, and countermeasures thereto, cf. ICRC, pp. 65-67. In short, "the substitution of human control over the targeting of weapons by electronic controls that are vulnerable to countermeasures...may have deleterious consequences for the discriminateness with which weapons can be used.” ibid., p. 67.

${ }^{21}$ Conversely, e.g. as per a Report prepared for further consideration, in 1972, "(t)here exists... a broad range of incendiary weapons designed for use both on the battlefield and against population centres and other vital targets)". Weaponry to be used against "population centers and other vital targets" denotes that as such they are strategic, rather than tactical, and the whole premise of humanitarian militarism is evinced once again thereby. Saint Petersburg Declaration, however, banned use of explosive bullets which had no precedent at that time, like blinding laser weapons later.
} 
exclusions or omissions, willingly or unwillingly, created by the regime under the CCW and Protocol IV together. This is particularly important to define the scope of application thereof, since the original CCW covers only international armed conflicts, whereby the amended CCW covers also non-international armed conflicts (Henckaerts \& Doswald-Beck, 2009, pp. 288-289; Zöckler, 1998; UNSG Factsheet, 2017)22.

Following the adoption of the Protocol IV, ICRC declares that she "welcomes the adoption...of a new legally binding instrument of humanitarian law prohibiting the use of laser weapons to blind soldiers or civilians" whereby "...a particularly barbarous form of warfare has been prohibited before it has ever been used" (Carnahan, 1996) ${ }^{23}$. To others, Protocol IV is “a landmark event in international humanitarian law”, since it “...indicates states' use of international humanitarian law to preempt a non-existing, but unwanted development: the use of blinding laser weapons...” (Symposium on Blinding Laser Weapons, 1996). Seen this way, Protocol IV is a success, and for a reason. Between the ICRC and Swedish approach for a total ban on blinding as a method of warfare and the US approach for a rather limited ban to permit use of laser devices, Protocol IV seems to include and mediate both approaches in principle (Zöckler, 1998, p. 334; Goldblat, 2003, p. 291; Henckaerts \& Doswald-Beck, 2009, pp. 292-296).

Thus, Article 1 reads: "It is prohibited to employ laser weapons...”, and the “...(p)arties shall not transfer such weapons to any (s)tate or non-(s)tate entity". But, only such laser weapons that are "specifically designed, as their sole combat function or as one of their combat functions, to cause permanent blindness to unenhanced vision...” are within the scope of the ban (UK Manual, 2005, ๆ 12.54.1, p. 323; ICRC, 1973, p. 69) ${ }^{24}$. Whereas as per Article 3, “(b)linding as an incidental or collateral effect of the legitimate military employment of laser systems, including laser systems used against optical equipment, is not covered by the prohibition of this Protocol”. The acceptance of the ban provided by the Protocol IV as establishing or emerging the customary rule of international law (Henckaerts \& Doswald-Beck, 2009, p. 355; Boothby, 2016, p. 205) ${ }^{25}$ is significant in this sense.

In this scheme, Protocol IV stipulates that: “(i)n the employment of laser systems, ...(p)arties shall take all feasible precautions to avoid the incidence of permanent blindness to unenhanced vision”, that such precautions include "training of...armed forces and other practical measures" (Art. 2). From the perspective of the US delegation, this Article is "intended to meet a concern of the Swedish delegation... not to undo with the one hand what the other hand accomplished in (a)rticle 1", though we are told that it is in line with internal guidance provided by the Secretary of Defense (Parks, 1997, pp. 38-39). Nonetheless, from the legalist perspective, this Article "contains an implicit recognition that blinding of individual combatants is an illegitimate use of laser systems” (Zöckler, 1998, pp. 337-338).

\footnotetext{
${ }^{22}$ Given the fact that proposals as to provide application of the Protocol in "armed conflict" and peace are rejected, some states (e.g. Australia, Austria, Germany, Ireland) declared that the ban "shall be observed at all times".

${ }^{23}$ The Vienna Review Conference: Success on Blinding Laser Weapons But Deadlock on Landmines, 35 INT’L REV. OF THE RED CROSS 672 (1995). As Carnahan puts it, this “...was a striking policy departure for the ICRC. For the first time in its history, the ICRC publicly denounced a specific method of warfare as a violation of international law”. But to him, ICRC "has only created confusion" rather than contribution, ibid., p. 731.

${ }^{24}$ Therefore, most of the laser devices may be deemed legal. "Permanent blindness" is further defined, or better put, deferred in the Protocol IV as well (Art. 4). Since laser weapons are deemed not to kill directly, the focus is on the human eye since late 1970’s.

${ }^{25}$ For the former opinion, see e.g. Henckaerts/Doswald-Beck, Rule 86, p. 355. For the latter opinion, see e.g. Boothby, p. 205. Boothby cautions against the scope of application of the Protocol IV in relation to the CCW, since not every state is inclined to apply the Protocol in non-international armed conflicts while ICRC commentators suggest and seem to rely on the CCW (Art. 1) amended in 2001 along with the ban on transfer (Protocol IV, Art. 1).
} 
1. Therefore, there exist legitimate and illegitimate uses, "method"s, and that are tied to two different meanings of "blinding" thereof. The first is banned; it is directly caused by employment of laser weaponry designed as such, and that is also illegitimate. However, the second is the indirect, namely incidental or collateral effect of legitimate use of laser weaponry; it is permitted. So, the legitimacy of such laser weaponry is defined as per the effect, the target (UK Manual, 2015, p. 116) ${ }^{26}$. And, that is why, for some, though the "ban gives nations the opportunity to forestall both a new weapons race and a humanitarian tragedy", the Protocol IV has a double "flaw": The Protocol "...does not prohibit production of these weapons and does not regulate anti-optical laser weapons that also target the eyesight" (Peters, 1996). Please also note that the "unenhanced vision" is defined in a way to include "the naked eye or...the eye with corrective eyesight devices" (Protocol IV, Art. 1). Therefore, crew of an armed fighting vehicle looking through binoculars may be blinded by an anti-matériel laser that is not designed to cause permanent blindness to unenhanced vision: In such a case, there would be no violation of the Protocol IV (Goldblat, 2003, pp. 291-292; Boothby, 2016, p. 205).

2. Furthermore, since production of blinding laser weapons is not banned and still continues, there exist problems for security experts. For instance, terrorists may acquire such weapons and comparison with other means or methods would be hard. In other words, when analyzing, “(d)edicated military blinding lasers such as those produced in Russia and China" cannot be used for "comparison because terrorist procurement of them would...be difficult” (Bunker, 2008). On this, such expert opines: though the blinding laser weapons are outlawed, such ban "is reminiscent of those...during the Middle Ages and Early Modern period...”, and "meaningless to those who ignore the laws of war such a criminal-soldiers", since "all that really matters is results...and the recognition of this fact by the terrorists themselves" (ibid., p. 440). This, however, coincides with the initial (op)position taken by the United States between 1975 and 1994 to refuse Swedish proposal lacking any evidence to support, and to any protocol on blinding laser weapons, since, according to a first-hand report, such opposition "was based in part on a concern that any protocol would affect lawful uses, which could place civilian populations and individual civilians at greater risk from less accurate” weaponry "while relinquishing or diminishing a lawful enhancement of tactical capabilities that enables United States forces to fight more effectively" (Parks, 1997, p. 34). Behind this and other ideas, of course, lies the scandalous dictum that "protocol should not prohibit the intentional use of a laser designed for other purposes to cause permanent blindness" (ibid., p. 36). If this view is accepted, why is the Protocol IV?

\section{Conclusion}

Taken the above mentioned stances summed up in points 1-2 together, one may easily perceive the stances and criticism of the same Protocol IV by both militarist humanitarianism and humanitarian militarism at work. The first stance is naive but ambitious, focuses "actively" on "spirit" or deed rather than work or word, congratulates the work or word achieved, then calls for further state action in the real spirit or deed without which any "dictate of public conscience" would fail to change the world, work or word as they stand, but unable to achieve what spirit or deed dictate in action. The second one is ridiculous, or better put, cynical in the sense that while assessing unnecessary suffering it focuses "scientifically" on "long-term social costs of warfare", "any terrorist” acquisition of or "comparison between" legally banned but actually permitted weapons, then "admit” that the legal outcome is "weak" or "meaningless”, require "a balancing of military utility against

\footnotetext{
${ }^{26}$ In one interpretation, if such effect occurs on the users of such equipment, it shall not be illegitimate, so not illegal.
} 
anticipated injuries", and criticize the effort of humanitarian action for lacking "support in state practice or other accepted sources of international law". In the midst of these extremes one may lean either to legalism of the technical lawyer or to politology of the security expert. However, one also constantly senses that the parties in dispute share much more than they differ. Whatever the consequences or stances are, though, in the background deals are made, projects are awarded.

The lines, however blurred, dividing the legal and factual, jurisprudence and nuclear sciences, humanities and natural sciences are of considerable size and effect (Bluntschli, 1881, pp. 271-278) ${ }^{27}$. When an issue is taken in a sphere or field as such, the outcome is generally predictable, e.g. in legal sphere, it is easy to predict that the narrative would be about rules, principles, courts, states, organizations, interpretations as well as exceptions, litigants, object, and purposes. Any such treaty, including the CCW or Protocol IV themselves presents perfect example for these remarks. Namely, an all-inclusive ban would prohibit any laser weapon in general and comprehensive way, since, at least from the experience of the ICRC we know that it is not relatively easy to distinguish peaceful and hostile, such a ban would include the physics, technology, and defense industry which indeed have paved the way for weaponry that causes superfluous injury or unnecessary suffering. By excluding the laser weapons that do not blind the enemy, the Protocol IV conditions itself upon and includes the distinction between what is blinding and who is enemy. Unable, or better put, impossible to prohibit the laser weapons that do not blind but destroy that is deemed to be militarily destroyable, the effort put forth by the international community is worth mentioning. The proposition by a commentator remains to be questioned: is it true that "if man does not master technology, but allows it to master him, he will be destroyed by technology", and if so, is not the question itself is that "man", and it is generally man, who is convinced that if any military technology is to be developed ever, it is for the purpose of killing the enemy? In other words, maybe the problem lies in our understanding of man's relation to technology. Perhaps, the situation is just the reverse, and the problem is that man masters technology much more than needed, and that we do not realize how it would be possible for us to conceive that surplus mastery is an unknown known to us.

Though it may sound weird, as a final remark, an example may be given by a recent development in a category of the weapons of mass destruction: nuclear weapons (ICRC, 1973, pp. 65-66) ${ }^{28}$. Adopted in July 2017, the Treaty on Nuclear Weapons aims to be universal; universally agreed, adopted, and implemented. However, the main impediment thereto is its being a treaty itself, a legal compromise diplomatically arranged, technically drafted, conventionally dealt, non-states-parties excluded. How can nuclear weapons be legally, politically, internationally dealt with otherwise? Although the number of voters to the Treaty is huge (122) by any standard, against the backdrop of the states who have not participated nor signaled any compromise with the initiative represented by the international community seen in the UN Conference, such backdrop remains as an obstacle to the realization of the object and purpose of the Treaty itself. In our opinion, repetition is worth to connote the limit of the ban envisaged by the Treaty, as is the case for the Protocol IV that limits: The nuclear

\footnotetext{
${ }^{27}$ Such size and effect should not be exaggerated. Take the example of the field marshal we cited earlier, which represents "humanitarian militarism". The marshal is (Graf, the elder) von Moltke and the international lawyer, (Johann Kaspar) Bluntschli. For the correspondence, see Bluntschli. The documentary mentioned above is titled "The First World War", and produced by Hamilton Film and Wark Clements in 2003. Quotes are from both the second episode, titled "Under the Eagle", centering on the events preceding, in and following German opening of hostilities in Belgium, and the other, the sixth, "Breaking the Deadlock" showing how after a year, soldiers adapted to war, and war adapted to them.

${ }^{28}$ For the general trend of increasing fire power in the battlefield, it includes the weapons of mass destruction. It is in such connection that we constantly refer to nuclear weapons. In another sense, the tendency of states to research or deploy high energy lasers is telling.
} 
weapons are legally declared illegal, but the ban is not legally binding on nuclear powers that hold nuclear weapons legally. Unlike the mainstream academia that are keen on but not being able to address the issues of armament and advance of technology, the more we face with novel developments in the field of defense industry, the more we think we are tempted to address the problems to their core. We agree to the view that this is the issue still at stake in various aspects of life (Zizek, 2006) ${ }^{29}$, not only for philosophy but also for legalism, optimist scientism, or pessimist humanitarianism as well.

\section{References}

Additional Protocol to the Convention on Prohibitions or Restrictions on the Use of Certain Conventional Weapons Which May Be Deemed to Be Excessively Injurious or to Have Indiscriminate Effects (Protocol IV), Oct. 13, 1995, 35 International Legal Materials, 1218 (1996) [Protocol IV].

Anderberg, B., Bring, O. E., \& Wolbarsht, M. L. (1992). Blinding laser weapons and international humanitarian law. Journal of Peace Research, 29(3), 287-297.

Anderberg, B., \& Wolbarst, M. L. (1992). Laser weapons: The dawn of a new military age. New York: Springer.

Berman, N. (2004-2005). Privileging combat? Contemporary conflict and the legal construction of war. Columbia Journal of Transnational Law, 43, 1.

Bilfinger, C. (1927). Deutschland und Völkerbund. Zeitschrift für Politik, 16, 283-285.

Bliss, T. H. (1926). What is disarmament? Foreign Affairs, 4, 353.

Bluntschli, J. K. (1881). Gesammelte kleine Schriften, Band II: Aufsätze über Politik und Völkerrecht. Nördlingen, C.H.Beck.

Boothby, W. H. (2016). Weapons and the law of armed conflict (2nd ed.). Oxford: OUP.

Braithwaite, J., \& Drahos, P. (2000). Global business regulation. Cambridge: CUP.

Bunker, R. J. (2008). Terrorists and laser weapons use. Studies in Conflict \& Terrorism, 31(5), 434-455.

Carnahan, B. M., \& Robertson, M. (1996). The protocol on “blinding laser weapons”. American Journal of International Law, 90(3), 484-490.

Carnahan, B. M. (1996). Unnecessary suffering, the red cross and tactical laser weapons. Loyola of Los Angeles International and Comparative Law Review, 18, 705-732.

Charter of the United Nations [UN] and Statute of the International Court of Justice [ICJ], Oct. 24, 1945. Available at: https://treaties.un.org/doc/source/docs/charter-all-lang.pdf [15.11.2017] [UN Charter, Statute of the ICJ respectively]

Chazel, F., \& Commaille, J. (1991). Normes juridiques et régulation sociale. Paris: LGDJ.

CNBC. Defense (2017). Lockheed gets air force contract to develop high-power airborne laser weapons. Available at: https://www.cnbc.com/2017/11/06/lockheed-martin-gets-air-force-contract-to-develop-airborne-high-power-laser-weapons.ht $\mathrm{ml}[15.11 .2017]$

Convention on Prohibitions or Restrictions on the Use of Certain Conventional Weapons Which May Be Deemed to Be Excessively Injurious or to Have Indiscriminate Effects, Oct. 10, 1980, 1342 UNTS 137 (1992) [CCW].

Corten, O. (2005). The controversies over the customary prohibition on the use of force: A methodological debate. European Journal of International Law, 16(5), 803.

Coupland, R. M. (1996). The effect of weapons. Medicine and Global Survival, 3.

Crawford, J., \& Koskenniemi, M. (Eds.). (2012). Cambridge companion to international law. Cambridge: CUP.

Declaration Renouncing the Use, in time of war, of explosive projectiles under 400 grammes weight. Nov. 29, 1868. Available at: https://ihl-databases.icrc.org/applic/ihl/ihl.nsf/Article.xsp?action=openDocument\&documentId=568842C2B90F4A29C1256 3CD0051547C [13.12.2017]

Defense News. (2017). MBDA secures $£ 30 \mathrm{M}$ laser weapon contract for UK. Available at: https://www.defensenews.com/global/europe/2016/09/16/mbda-secures-ps30m-laser-weapon-contract-for-uk/ [15.11.2017]

Deleuze, G. (1993). Différence et répétition (7e édition). Paris: PUF.

Doswald-Beck, L. (1996). New protocol on blinding laser weapons. International Review of the Red Cross Archive, $36,272$.

Downs, R. L. (2007). Less lethal weapons. Policing: An International Journal, 30(3), 358.

Efremoff, J. (1932). Le désarmement moral et la conciliation internationale. Esprit International, 6, 419.

\footnotetext{
${ }^{29}$ For an illuminating interpretation, response to and reflection on mainstream politics, demagogy, enthusiasm on technology etc.
} 
Fidler, D. P. (2001). “Non-lethal” weapons and international law. Medicine, Conflict and Survival, 17(3), 194-206.

Fleischmann, W. M. (2015). Just say “no!” to lethal autonomous robotic weapons. Communication and Ethics in Society, 13(3/4), 299.

Goldblat, J. (2003). Arms control, reprint of new edition. London: Sage.

Human Rights Watch [HRW]. (May, 1995). Arms project: U.S. blinding laser weapons. Available at: https://www.hrw.org/reports/1995/Us2.htm [15.11.2017]

Henckaerts, J. M., \& Doswald-Beck, L. (2009). Customary international humanitarian law (Vol. I). Reprinted with corrections. Cambridge: ICRC, CUP.

ICRC. (1973). Weapons that may cause unnecessary suffering or have indiscriminate effects: Report on the work of experts. Geneva.

Jane's 360. (2017). Firebreathing dragon. Available at: http://www.janes.com/article/73896/firebreathing-dragon-dsei17d2 [15.11.2017]

Kalshoven, F. (1985). Arms, armaments and international law. Recueil des Cours, 191.

Kennedy, D. (2006). Reassessing the humanitarian promise of the international legal tradition. Zeitschrift für Schweizerisches Recht., 125, 133.

Koskenniemi, M. (1997). Case analysis: Faith, identity, and the killing of the innocent. Leiden Journal of International Law, 10, 137.

Koskenniemi, M. (2010). Human rights mainstreaming as a strategy for institutional power. Humanity: An International Journal of Human Rights, 1(1), 47-58.

Koskenniemi, M. (2005). International legislation today. Wisconsin International Law Journal, 23, 61.

Krause, K. (1995). Arms and the state: Patterns of military production and trade (First paperback edition). Cambridge: Cambridge University Press.

Kunz, J. L. (1929). Zur Abrüstungsfrage. Zeitschrift für die gesamte Staatswissenschaft, 87, 387.

Lauterpacht, H. (1934). The pact of Paris and the Budapest articles of interpretation. Transactions of the Grotius Society, $20,178$.

Legality of the Threat or Use of Nuclear Weapons, Advisory Opinion, 1996 ICJ Rep. 226 (July 8) [Nuclear Weapons Opinion].

Le Fur, L. (1934). La Société des Nations et la crise actuelle. Séances et Travaux de L'Académie de Sciences Morales et Politiques, 94, 90.

Lewis, M. W. (2008-2009). Ethics and operational realities of the war on terror. South Texas Law Review, $50,837$.

Lewis, M. W. (2003). The law of aerial bombardment in the 1991 Gulf War. American Journal of International Law, 97, 481.

Military and Paramilitary Activities in and against Nicaragua (Nicar. v. USA), Judgment, 1986 I.C.J. Rep. 14 (June 27) [Nicar. v. USA].

Noel-Baker, P. (1927). Le désarmement et la Conférence Coolidge. Esprit International, 1, 463.

Niemeyer, T. (1928). Handbuch des Abrüstungsproblems, Systematischer Teil. Berlin u. Grunewald, Walther Rothschild.

Parks, W. H. (1997). Memorandum of law. Army Lawyer, 33.

Peters, A. (1996). Blinding laser weapons. Medicine, Conflict and Survival, 12, 107.

Peters, A. (1996). Blinding laser weapons: New limits on the technology of warfare. Loyola of Los Angeles International and Comparative Law Review, 18, 733.

Pictet, J. (1966). The principles of international humanitarian law. International Review of the Red Cross, 6.

Politis, N. (1925). Les accords de Locarno. Revue de Droit International et Droit Comparé, 6, 713.

Pomme de Mirimonde, A. (1920). Les traités imparfaits. Paris: Jouve\&C ${ }^{\text {ie }}$.

Protocol Additional to the Geneva Conventions of 12 August 1949, and relating to the Protection of Victims of International Armed Conflicts (Protocol I), Jun. 8, 1977, 1125 UNTS 3 [Protocol I 1977].

Ray, J. (1936). L'eventuelle reforme de la Société des Nations. Revue de Droit International et Droit Comparé, 17, 225.

Roberts, A. (1999). The role of humanitarian issues in international politics in the 1990s. International Review of the Red Cross, $81,19$.

Rumsfeld, D. (2011). Known and unknown: A memoir. London: Penguin.

Sandoz, Y., Swinarski, C., \& Zimmermann, B. (Eds.). (1987). Commentary on the additional protocols. Geneva, Martinus Nijhoff.

Sands, P. (2005). Lawless world. Melbourne Journal of International Law, 6, 437.

Scelle, G. (1934). Essai sur la crise de la Société des Nations et ses remèdes. Esprit International, 8, 163.

Strawson, J. (2002). Law after ground zero. Portland, Newport, Glass House Press. 
Symposium on Blinding Laser Weapons. (1996). Loyola of Los Angeles International and Comparative Law Review, $18,703$.

The Vienna Review Conference: Success on Blinding Laser Weapons but Deadlock on Landmines. (1995). International Review of the Red Cross, 35, 672.

Tönnies, F. (1929). Das Abrüstungsproblem. Zeitschrift für Politik, 18, 721.

Treaty on the Prohibition of Nuclear Weapons, UN Doc. A/CONF.229/2017/8, 07.07.2017. Available at: http://undocs.org/A/CONF.229/2017/8 [15.11.2017]

Tuzmukhamedov, B. (2015). Legal dimensions of arms control agreements. Recueil des Cours, 37, 327.

UK Iraq Inquiry Committee. (2016). Report of the Iraq Inquiry, each of the 12 (twelve) volumes are available at: http://www.iraqinquiry.org.uk/the-report/ [15.11.2017]

UK Ministry of Defence. (2005). The manual of the law of armed conflict (Paperback edition). Oxford, New York, OUP, [UK Manual].

UN Secretary General. Multilateral treaties deposited with secretary general (2017). Chapter XXVI.2a. Available at: https://reaties.un.org/doc/Publication/MTDSG/Volume\%20II/Chapter\%20XXVI/XXVI-2-a.en.pdf [15.11.2017] [UNSG Factsheet]

UN Secretary General. (1972). Report: Napalm and Other Incendiary Weapons and All Aspects of Their Possible Use, UN Doc. $\mathrm{A} / 8803$.

Von Oertzen, K. L. (1931). Abrüstung oder Kriegsvorbereitung? Berlin: Zentralverlag.

Wehberg, H. (1919). Die internationale Beschränkung der Rüstungen. Stuttgart $u$. Berlin: Deutsche Verlags-Anstalt.

Wehberg, H. (1920). Als Pazifist im Weltkrieg. Leipzig: Der Neue Geist.

Wehberg, H. (1925). Abrüstung oder Rüstungsbeschränkung? Die Friedens-Warte, 25, 4.

Zizek, S. (2006). Philosophy, the “unknown knowns”, and the public use of reason. Topoi, 25, 137.

Zizek, S. (2008). For they know not what they do (2nd ed.). London, Verso.

Zöckler, M. C. (1998). Commentary on protocol IV on blinding laser weapons. Yearbook of International Humanitarian Law, 1, 333.

Zohuri, B. (2016). Directed energy weapons: Physics of high energy lasers (HEL). Switzerland: Springer. 